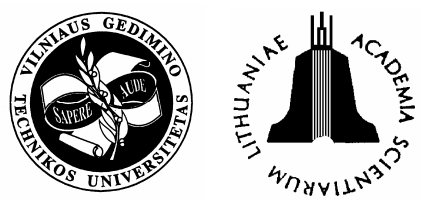

\title{
EXPERIMENTAL RESEARCH ON THE DEVELOPMENT OF RUTTING IN ASPHALT CONCRETE PAVEMENTS REINFORCED WITH GEOSYNTHETIC MATERIALS
}

\author{
Alfredas Laurinavičius ${ }^{1}$, Rolandas Oginskas ${ }^{2}$ \\ Dept of Roads, Vilnius Gediminas Technical University, \\ Saulètekio al. 11, LT-10223 Vilnius, Lithuania, \\ E-mail: ${ }^{1}$ Alfredas.Laurinavicius@ap.vtu.lt ${ }^{2}$ Rolandas.Oginskas@ap.vtu.lt \\ Received 14 Nov 2005; accepted 17 May 2006
}

\begin{abstract}
The article sets out to explore reasons for the development of shear strains and rutting in asphalt pavement as well as to suggest and describe the main methods for reducing the deformation. The impact of geosynthetic materials is defined through reological characteristics of asphalt: the modulus of elasticity and the viscosity of asphalt. The research has been conducted on the experimental road section in the city of Vilnius. The measurements have been based on the plate-bearing test. Sustaining the measurements results is defining the dependency of geosynthetics materials on the depth of rutting and the modulus of elasticity of asphalt concrete. The paper also includes regression equations which show the interdependence of the modulus of elasticity of asphalt concrete and the depth of rutting.
\end{abstract}

Keywords: asphalt concrete, asphalt reinforcement, geosynthetics, the modulus of elasticity of asphalt concrete, the depth of rutting.

\section{Introduction}

Asphalt concrete under the influence of freight traffic is subjected to stress which leads to a variety of strains.

Rutting is one of the main types of strains, which are difficult to count and simulate due to the following reasons [1]:

1. The key relations between material characteristics are non-linear and complex. The majority of materials of asphalt concrete are difficult to define due to a frequent impact of the repeated mobile loading.

2. The changes of material characteristics under heavy loading and high temperature set up a prerequisite to investigate asphalt concrete as viscoelastic material. However, materials of the road base, frost-resistant courses and the embankment hardly depend on the above variables.

3. The temperature and humidity of the materials differ in each cycle of repeated loading. Therefore it is important to predict mechanisms of rut formation in different types of material, structures, traffic flows and the environment.

The reasons of residual strains lie in the compaction of different pavement layers (structural ruts) and shear strains (ruts in the wearing course of asphalt concrete).

The first problem of rutting has been dealt with in order to decrease vertical stress on the surface of the road base. Such strains emerge in all layers of flexible pavement. There was a solution found by reinforcing the base, ie increasing its elastic modulus.
Ruts occurring in the wearing course of asphalt concrete seem to cause a more serious problem. Ruts emerge as a result of accumulated residual strains in the wearing course of asphalt concrete [2].

Ruts are treated as dangerous defects, since they might cause danger for traffic, especially when the pavement is wet [3]. The maximum permissible depth of ruts in the Republic of Lithuania is $20 \mathrm{~mm}$. The results of measured rutting [4] have testified that presently about $2 \%$ of the road network exceed the maximum permissible limit of rut depth (Table 1).

Table 1. Distribution of ruts according to depth, \%

\begin{tabular}{c|c}
\hline Rut depth (mm) & \% \\
\hline$<5$ & 52,0 \\
\hline $5-10$ & 31,0 \\
\hline $10-15$ & 11,3 \\
\hline $15-20$ & 3,9 \\
\hline $20-30$ & 1,5 \\
\hline$>30$ & 0,3 \\
\hline
\end{tabular}

The main reason for shear strains is concerned with shear stress occurring in asphalt concrete pavement in operation [1]. The probability of shear strains in asphalt concrete is higher when the pavement temperature is high [5]. Neutralising stresses ' and increasing the stress resistance of asphalt concrete could solve the problem.

The problem has been in the focus of attention of researchers for years. The first attempts to solve it were made in the beginning of 1950 , when research focused on 
improving the characteristics of asphalt concrete by improving the indicators of asphalt concrete mixture.

A number of tests have been carried out to investigate the impact of the interior angle of friction of asphalt concrete mixture on rutting and skid-resistance [2]. The parameters vary depending on particle size analysis of asphalt concrete mixture, the amount of bitumen and its cohesion with aggregate. Also the parameters depend on the temperature of the environment. The results were obtained by the three-axle method and simulating the dynamic load. The investigation has resulted in establishing that two parameters are equally important for the shear stress resistance of asphalt concrete. The higher the cohesion and the interior friction angle, the higher the bearing capacity of asphalt concrete.

The form and nature of aggregate has considerable impact on the characteristics of asphalt concrete mixtures. The impact of those variables is identified in a laboratory, on the basis of the depth of rutting in asphalt concrete [6]. If the material used is split or of a higher quality, ruts are not so deep. Also the characteristics of dynamic stiffness, stability and durability are improved.

Mineral fillers are the part of asphalt mixture, which determines the properties of asphalt concrete. The influence of these materials on the strength properties of asphalt concrete has been established with the help of mathematical modelling and laboratory work [7].

The particle size of the asphalt mixture and the amount of bitumen exert a considerable impact on physical and mechanical characteristics of asphalt concrete, which, in their turn, influence the formation of shear strains in asphalt concrete pavements. The optimum amount of bitumen and the particle size improve the physical and mechanical characteristics of asphalt concrete as well as shear stress resistance of asphalt concrete [8].

Over the years, quite extensive research has been done on using bitumen in asphalt concrete mixture. It has been identified that the depth of rutting depends on the stiffness of asphalt concrete mixture, which, in its turn, depends on the stiffness of bitumen $[9,10]$. To reduce the depth of rutting, there is also a polymer-modified bitumen used.

Previous research has measured and assessed the reological parameters of asphalt concrete [11].

Rutting is a serious problem. It has been dealt with applying both - traditional (mixtures of crushed granite and asphalt concrete mastic, all sorts of additives in asphalt concrete mixtures) as well as modern methods. One of the latter is concerned with geosynthetic-reinforced asphalt concrete.

Reinforcing pavements is not an absolutely new phenomenon; it has been sufficiently well investigated. However, the majority of investigations have been concentrated on reinforcing the road base and the embankment by geosynthetics [12, 13]. Research into reinforcing asphalt concrete has been concerned with the prevention of reflection cracking [14, 15]. However, very little research has been conducted into the impact of reinforced asphalt concrete on the formation of plastic and shear strains in asphalt concrete.

In Lithuania geosynthetic materials were first used in 1996 with the purpose of reducing reflection cracking. As a result several observations were made. They had no scientific grounding on how geosynthetics influences shear strains and rutting.

The present study aims at establishing the practical benefit of the reinforcement with geosynthetic materials, which would reduce shear strains and rutting.

\section{The impact of geosynthetic reinforcement on the characteristics of asphalt concrete}

Asphalt concrete is a type of material which is produced by compacting a special mixture, consisting of crushed rock or gravel, sand or crushed stone, filler and bitumen, all selected in relevant proportions. Asphalt concrete acquires the required physical and mechanical qualities only after compaction.

Under different environmental conditions asphalt concrete can have different forms of physical existence:

- Plastic;

- Viscoelastic;

- Elastic.

The theory of elasticity and plasticity describes the qualities of asphalt concrete exclusively at some selected points of states of existence and does not provide a complete view of asphalt concrete operation. It is reology, a science about the fluidity of materials, that gives the most complete and precise description of the asphalt concrete operation. When making the calculating model of asphalt concrete, reology makes use of dependences of several mechanical models. For investigating the asphalt concrete as viscoelastic material, usually Burgers' model is considered the most appropriate [16] and described by the following dependence:

$$
\varepsilon=\frac{\sigma}{E_{0}}\left(1+\frac{t}{T_{0}}\right)+\frac{\sigma}{E_{1}}\left[1-\exp \left(-\frac{t}{T_{1}}\right)\right],
$$

where $\sigma$ stands for stresses, $E_{0}$ - modulus of elasticity of an element series, $E_{l}$ - modulus of elasticity of an isolated element, $T_{0}, T_{1}$ - time of relaxation of asphalt concrete, $T_{0}=\eta / E_{0}, T_{1}=\eta / E_{1}, \eta$ - viscosity, $t$ - time.

However, viscoelastic materials are best characterised by another parameter, creep compliance, which in a general case is expressed as:

$$
D(t)=\frac{\varepsilon(t)}{\sigma},
$$

where $\varepsilon(t)$ stands for a time-dependent strain under the influence of continuous loading.

When describing viscoelastic materials according to Burgers' model, the creep compliance is expressed in the following manner:

$$
D(t)=\frac{1}{E_{0}}\left(1+\frac{t}{T_{0}}\right)+\frac{1}{E_{1}}\left[1-\exp \left(-\frac{t}{T_{1}}\right)\right] .
$$


Reinforcing is a structural measure increasing strength. Reinforcing road pavement is concerned with increasing pavement resistance to a variety of stresses and improving its strength characteristics. It refers to mobilising stresses in some layers, more specifically, in geosynthetics and higher values of some selected parameters.

When reinforcing pavement by geosynthetics, the reological model of asphalt pavement changes. On the basis of equation (3), reflecting the creep compliance of asphalt concrete, the following assumptions can be made:

- Reinforcing asphalt concrete by geosynthetics influences its modulus of elasticity $(E)$,

- Reinforcing asphalt concrete by geosynthetics influences its viscosity $(\eta)$.

The above characteristics are the key factors in deciding the resistance of asphalt concrete to shear strains.

The above stress interpretation $[9,16]$ and the results of the investigation of reinforced pavement $[17,18]$ lead to a conclusion that the modulus of elasticity of asphalt concrete is influenced by reinforcement.

Asphalt concrete viscosity characterises the period of asphalt concrete strain under shear stresses and determines asphalt concrete in one or another physical condition. Higher viscosity characterises asphalt concrete as an elastic body and vice versa. In the elastic asphalt concrete no shear strains emerge.

The model is expressed as:

$$
D(t)=\frac{1}{E_{0 R}}\left(1+\frac{t}{T_{0 R}}\right)+\frac{1}{E_{1 R}}\left[1-\exp \left(-\frac{t}{T_{1 R}}\right)\right],
$$

where $E_{0 R}=E_{0} \times k_{E_{0}}$ refers to a reduced modulus of elasticity of an element series; $E_{1 R}=E_{1} \times k_{E_{1}}-$ reduced modulus of elasticity of an isolated element; $T_{0 R}=T_{0} \times k_{T_{0}}-$ reduced viscosity of an element series; $T_{1 R}=T_{1} \times k_{T_{1}}$ - reduced viscosity of an isolated element; $k_{E}, k_{E 1}, k_{T 0}, k_{T 1}$-indices reflecting the impact of reinforcing on isolated elements of the reological model.

The parameters are presumptive. After the research is completed, the parameters will be proved or refuted.

\section{Experimental research}

The impact of reinforcement on the characteristics of asphalt concrete is identified in a laboratory or experimental sections in roads [17]. There are several testing methods; however, the main principle remains the same. The testing is performed on a laboratory stand or experimental sections on roads, where the pavement structure is being tested. One or several sections are reinforced by geosynthetics; one section is not reinforced and serves as a control testing section. Loading on the pavement structure, depending on the testing method, can be transferred by a dynamic load plate test as well as a wheel load test, which simulates the traffic load or when the traffic is not interrupted, on the testing section. The key aim of investigating reinforced pavement is to identify the impact of geosynthetics and to assess its efficiency when the asphalt concrete pavement is in operation $[17,18]$.
At the time of testing the values of a number of quality and quantity parameters as well as their dependence on reinforcement are identified [17, 18].

The key aims of research are as follows:

- To verify previous assumptions on which characteristics of asphalt concrete are mostly influenced by reinforcement.

- To identify the importance of these factors.

- To substantiate the efficiency of reinforcement of road structures.

To attain the above aims, the following objectives have been set:

- To identify during the plate load test the dependence between the depth of plate sinking and the load under different temperatures.

- To identify strain characteristics of asphalt concrete: the modulus of elasticity of reinforced road structures.

- To identify values of the modulus of elasticity of asphalt concrete and its viscosity in their dependence on reinforcing by geosynthetics.

To be able to identify the impact of reinforcement on the variability in the modulus of elasticity of asphalt concrete and its viscosity, the authors initiated the construction of a testing section.

\subsection{The experimental section}

In the city of Vilnius, there has been a testing road section constructed (Fig 1). The experimental section has been constructed in September 2004 and was geosynthetic-reinforced (Fig 2).

In order to identify the impact of reinforcement on the reological characteristics and strains of asphalt concrete, a layer of asphalt concrete was reinforced; ie geosynthetics was laid between the first and the second layer of asphalt concrete.

The experimental pavement construction consists of the following layers (Fig 2):

- $4 \mathrm{~cm}$ thickness 0/11 S-M asphalt concrete layer (asphalt layer No 1),

- $5 \mathrm{~cm}$ thickness 0/16 S-A asphalt concrete layer (asphalt layer No 2),

- $6 \mathrm{~cm}$ thickness 0/22 A asphalt concrete layer (asphalt layer No 3),

- $25 \mathrm{~cm}$ thickness crushed stone layer (the base), $40 \mathrm{~cm}$ thickness frost-resistant layer (the subgrade). The geosynthetic materials used are presented in Table 2 .

Table 2. The geosynthetic materials used

\begin{tabular}{l|c}
\hline \multicolumn{1}{c}{ The material } & The area of used material $\mathrm{m}^{2}$ \\
\hline Geogrids & 35 \\
\hline HaTelit C 40/17 & 35 \\
\hline Bitutex Stargrid Glu 50 & 35 \\
\hline Armapal MP-50 & 70 \\
\hline Geotextiles & 70 \\
\hline Pavemat & 70 \\
\hline Pavegrid G-50 &
\end{tabular}



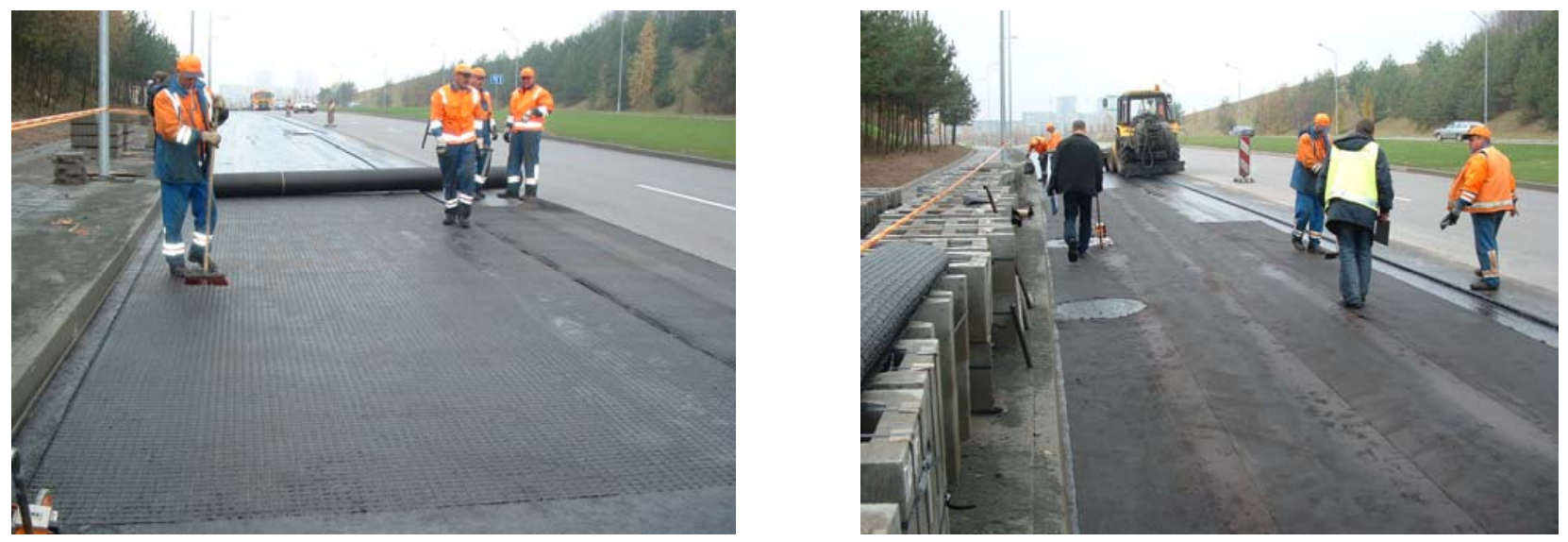

Fig 1. The equipment of experimental section

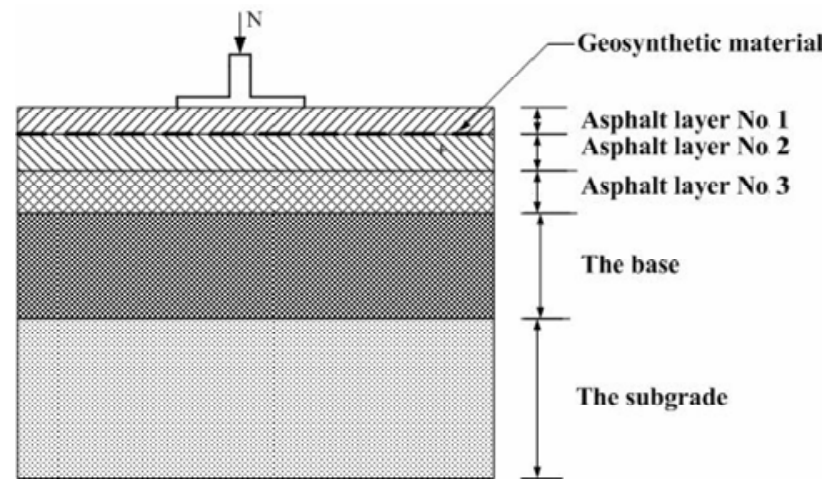

Fig 2. Geosynthetic-reinforced pavement research scheme

The asphalt concrete layers on the whole testing section were of equal thickness, of the same type and composition. The elasticity modulus of the road base, frostresistant layers and the embankment was the same on the total length of the asphalt concrete section; therefore, it is taken as a non-variable value. Hence, the variability of different values is associated solely with the reinforcement of asphalt concrete.

During the first stage of experimental research the following parameters have been measured: the modulus of elasticity of asphalt concrete $E$, the depth of rutting. The first measurement of the depth of rutting was accomplished in April 2005, the second - in September, immediately after the hot season. The modulus of elasticity was measured in September 2005. Table 3 provides the results of experimental measurements based on the plate-bearing test [19].

The modulus of elasticity has been measured 10 times in every sector with a different geosynthetic. The numbers of experimental measurements have been calculated on the basis of previous measurements of the same pavements construction. The depth of rutting has been measured 10 times in sectors with geogrids and 20 times in sectors with geotextiles.

The rutting depth has been measured in different seasons of the year with the purpose to estimate how geosynthetics influences the development of these strains in different seasons.

\subsection{The analysis of experimental data}

The analysis begins with the rutting depth. Fig 3 and Table 3 present the depths of rutting after two measurements.

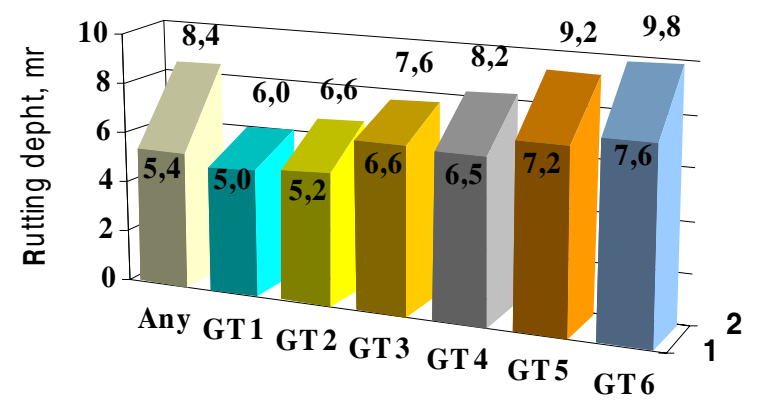

The code of used geosynthetics

Fig 3. Increase of the rutting depth

Numbers 1 and 2 reflect the measurements of rutting in spring and autumn, respectively.

After the first measurement in spring, it has been identified that the rutting depth does not depend on the geosynthetic material.

In section without geosynthetics, the depth of rutting was less than in sections with geosynthetics.

However, after the second measurement the influence of geosynthetics has been clearly identified (Fig 3).

The regression analysis (Figs 4-6) has shown a clear relationship between the depth of rutting and the modulus of elasticity of asphalt concrete, particularly in the first case of rutting. However, the relationship between the increase of the depth of rutting and the modulus of elasticity of asphalt concrete is not marked.

Below is shown the statistical expression of the dependence of the first measurements of the rutting depth on the modulus of elasticity:

Fitted regression model:

$$
Y=1 /\left(a+b \times X^{2}\right) \text {. }
$$


Table 3. The data of experimental measurements of reinforced asphalt pavements

\begin{tabular}{|c|c|c|c|c|c|c|c|c|}
\hline \multirow{2}{*}{$\begin{array}{l}\text { The } \\
\text { code of } \\
\text { geosyn- } \\
\text { thetic }\end{array}$} & \multicolumn{2}{|c|}{$\begin{array}{l}\text { The rutting depth after } \\
\text { first measurement }\end{array}$} & \multicolumn{2}{|c|}{$\begin{array}{l}\text { The rutting depth after } \\
\text { second measurement }\end{array}$} & \multirow{2}{*}{$\begin{array}{l}\text { The increase of } \\
\text { the rutting depth } \\
\Delta h=\bar{h}_{1}-h_{2}, \mathrm{~mm}\end{array}$} & \multicolumn{3}{|c|}{ The modulus of elasticity } \\
\hline & $\begin{array}{r}\bar{h}_{1}, \\
\mathrm{~mm}\end{array}$ & $\begin{array}{c}\text { Statistical } \\
\text { parameters }\end{array}$ & $\begin{array}{r}\bar{h}_{2}, \\
\mathrm{~mm}\end{array}$ & $\begin{array}{c}\text { Statistical } \\
\text { parameters }\end{array}$ & & $\begin{array}{c}\bar{E} \\
\mathrm{MPa}\end{array}$ & $\begin{array}{c}\text { Statistical } \\
\text { parameters }\end{array}$ & $k_{E}$ \\
\hline Any & 5,4 & $\begin{array}{c}\sigma=0,93 \mathrm{~mm} \\
R=17,4 \%\end{array}$ & 8,4 & $\begin{array}{c}\sigma=1,37 \mathrm{~mm} \\
R=16,4 \%\end{array}$ & 3,0 & 347 & $\begin{array}{c}\sigma=34,23 \mathrm{MPa} \\
R=9,9 \%\end{array}$ & 1,00 \\
\hline GG1 & 5,0 & $\begin{array}{c}\sigma=1,46 \mathrm{~mm} \\
R=29,3 \%\end{array}$ & 6,0 & $\begin{array}{c}\sigma=1,94 \mathrm{~mm} \\
R=31,1 \%\end{array}$ & 1,0 & 359 & $\begin{array}{c}\sigma=30,35 \mathrm{MPa} \\
R=8,5 \%\end{array}$ & 1,03 \\
\hline GG2 & 5,2 & $\begin{array}{c}\sigma=0,98 \mathrm{~mm} \\
R=18,7 \%\end{array}$ & 6,6 & $\begin{array}{c}\sigma=0,94 \mathrm{~mm} \\
R=14,3 \%\end{array}$ & 1,4 & 351 & $\begin{array}{c}\sigma=23,14 \mathrm{MPa} \\
R=6,6 \%\end{array}$ & 1,02 \\
\hline GG3 & 6,6 & $\begin{array}{c}\sigma=0,86 \mathrm{~mm} \\
R=13,1 \%\end{array}$ & 7,6 & $\begin{array}{c}\sigma=1,50 \mathrm{~mm} \\
R=19,5 \%\end{array}$ & 1,0 & 306 & $\begin{array}{c}\sigma=12,76 \mathrm{MPa} \\
R=4,2 \%\end{array}$ & 0,89 \\
\hline GT1 & 6,5 & $\begin{array}{c}\sigma=1,14 \mathrm{~mm} \\
R=17,5 \%\end{array}$ & 8,2 & $\begin{array}{c}\sigma=1,57 \mathrm{~mm} \\
R=19,0 \%\end{array}$ & 1,7 & 291 & $\begin{array}{c}\sigma=12,89 \mathrm{MPa} \\
R=4,3 \%\end{array}$ & 0,83 \\
\hline GT2 & 7,2 & $\begin{array}{c}\sigma=0,87 \mathrm{~mm} \\
R=12,1 \%\end{array}$ & 9,2 & $\begin{array}{c}\sigma=0,91 \mathrm{~mm} \\
R=9,9 \%\end{array}$ & 2,0 & 258 & $\begin{array}{c}\sigma=18,41 \mathrm{MPa} \\
R=7,1 \%\end{array}$ & 0,75 \\
\hline GT3 & 7,6 & $\begin{array}{c}\sigma=1,79 \mathrm{~mm} \\
R=23,7 \%\end{array}$ & 9,8 & $\begin{array}{c}\sigma=1,28 \mathrm{~mm} \\
R=13,2 \%\end{array}$ & 2,2 & 277 & $\begin{array}{c}\sigma=15,99 \mathrm{MPa} \\
R=5,8 \%\end{array}$ & 0,80 \\
\hline
\end{tabular}

$\sigma-$ Standard deviation, $R$ - Coefficient of variation, $k_{E}$ - coefficient of reinforcement.

The values of $\bar{h}_{1}, \bar{h}_{2}$ and $\bar{E}$ are statistical averages of variable series.

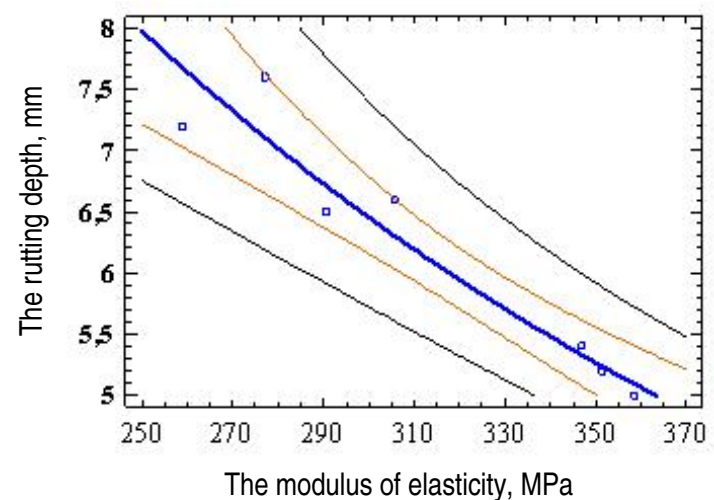

Fig 4. Dependence of the rutting depth on the modulus of elasticity after the first measurement model:

The numerical expression of the fitted regression

$$
h_{1}=1 /\left(0,0585+0,00000107 \times E^{2}\right) .
$$

R-Squared $=94,3 \%$, F-Ratio $=83,1$.

The statistical expression of the dependence of the second measurements of the depth of rutting on the modulus of elasticity is as follows:

Fitted regression model:

$$
Y=\left(a+b \times X^{2}\right)^{2} .
$$
model:

The numerical expression of the fitted regression

$$
h_{2}=\left(3,6-0,00000797 \times E^{2}\right)^{2} .
$$

R-Squared $=66,2 \%$, F-Ratio $=9,8$.

The statistical expressions of dependence of the increase of the depth of rutting on the modulus of elasticity are follows:

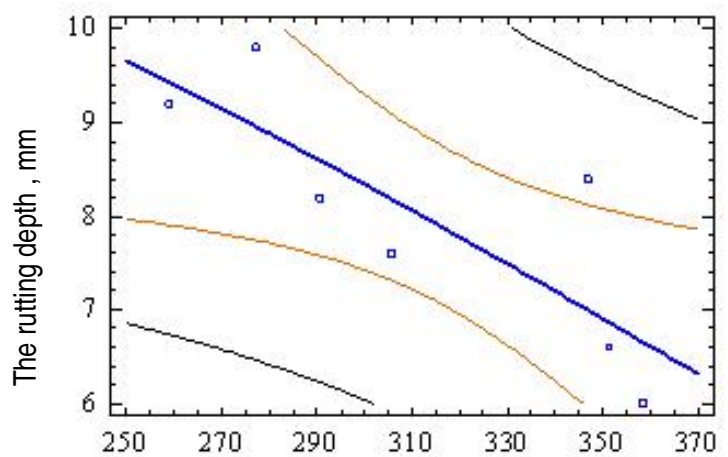

The modulus of elasticity, MPa

Fig 5. Dependence of the rutting depth on the modulus of elasticity after the second measurement

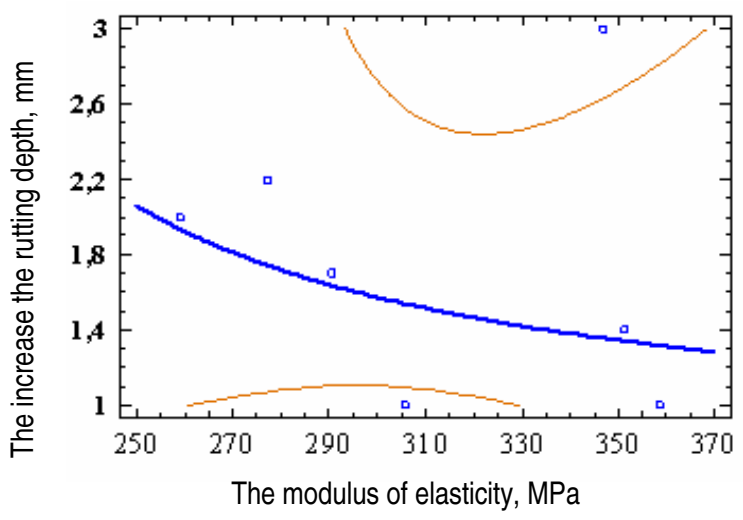

Fig 6. Dependence of the increase of the rutting depth on the modulus of elasticity 
Fitted regression model:

$$
Y=1 /(a+b / X) \text {. }
$$
model:

The numerical expression of the fitted regression

$$
\Delta h=1 /(1,38-224,6 / E) .
$$

R-Squared $=12,8 \%$, F-Ratio $=0,7$.

The regression models have been fitted by the best R-squared value.

R-squared measures the percentage of variability in $\mathrm{Y}$ that has been explained by the fitted model. R-squared is calculated from:

$$
R^{2}=100\left(1-\frac{\sum_{i=1}^{n}\left(y_{i}-\hat{y}_{i}\right)^{2}}{\sum_{i=1}^{n}\left(y_{i}-\bar{y}\right)^{2}}\right), \%,
$$

where: $y_{i}-$ the observed value of $\mathrm{Y} ; \hat{y}_{i}-$ the predicted value from the fitted model.

Little R-squared shows low relations in the fitted regression model. The last regression dependence must be eliminated from the statistical analysis. Low correlation coefficient and low R-squared show that statistical relations are non-existent. Consequently, the modulus of elasticity does not influence the development of rutting in a hot season.

The adequacy of the regression model verified the sustained statistical parameter $F$ (dispersion ratio) and calculated it in the following manner:

$$
F=\frac{S_{\frac{2}{y}}^{2}}{S_{r e s}^{2}},
$$

where $S_{\frac{1}{y}}^{2}-$ the dispersion of regression model; $S_{\text {res }}^{2}-$ the residual dispersion.

F-value is compared with $F_{c r}$ (F critical); if F-value $>F_{c r}$, the model is adequate. Hence, the first and the second regression models are adequate (F-ratio $>1$ ); and the third model is inadequate.

The homogeneity of variance was checked by applying the Bartlett criterion to determine if there is any statistical difference in the stability of the components calculated from the test data on various samples [20]. When the calculated B (Bartlett criterion) is lower than $\chi^{2}$ (chi-squared), the null hypothesis is adopted.

$$
B=\frac{2,303\left(k \lg \bar{S}^{2}-\sum_{i=1}^{l} k_{i} S^{2}\right)}{1+\frac{1}{3(l-1)}\left[\sum_{i=1}^{l} \frac{1}{k_{i}}-\frac{1}{k}\right]} \leq \chi^{2},
$$

where: $\bar{S}$ - average weighed standard deviation, $\%$ and calculated by the formula:

$$
\bar{S}=\left[\frac{\sum_{i=1}^{l} k_{i} S_{i}^{2}}{k}\right]^{\frac{1}{2}},
$$

where: $S_{i}$ - standard deviation of the content of measurements; \%; $k_{i}$ - degree of freedom $k_{i}=n_{i}-1, k=\sum_{i=1}^{l} k_{i}$; 1 - number of the compared measurement locations.

All variance is homogenous, because the Bartlett criterion is lower than the chi-square values (Table 4).

Table 4. The numerical values $B$ and $\chi^{2}$

\begin{tabular}{l|c|c|c}
\hline & $E$ & $S_{1}$ & $S_{2}$ \\
\hline Bartlett's criterion B, & 1,3 & 2,03 & 1,12 \\
\hline$\chi^{2}$ chi-squared & 135,0 & 47,3 & 53,6 \\
\hline
\end{tabular}

All statistical dependencies, Bartlett criterion, multiple regression coefficient (R-squared), chi-squared, F-Ratio and other statistical parameters have been calculated with the statistical software Statgraphics Centurion XV.

The coefficient of reinforcement shows the increase of the elasticity modulus on two experimental sections. In other sections the modulus is less than on sections that have not been reinforced.

The coefficient $k_{E}$ can be used in Eq (4) to calculate creep compliance.

Because the relation between the increase of the depth of rutting and the modulus of elasticity of asphalt concrete is low, so are the other factors, which influence this increase. To this end the research is being continued.

\section{Conclusions}

1. Geosynthetics has been used to decrease shear strains in asphalt concrete layers without any obvious scientific grounding, exclusively on the basis of theoretical assumptions. The present research has shown that on several occasions the use of some materials is inexpedient.

2. The research has established the dependence of the rutting depth on the modulus of elasticity as the first condition of rutting. In its turn, the modulus of elasticity of asphalt concrete depends on the type of geosynthetic material used. To improve the strength properties of asphalt concrete it is expedient to use geogrids.

3. The accomplished research into reinforced asphalt concrete has established that the rutting depth depends on the type of geosynthetic material used. The rutting depth increases from 1,4 to 2,2 times with geosynthetic materials and 3 times without a geosynthetic material. However, to reduce shear strains and rutting, it is expedient to use geogrids.

4. The deduced regression model allows calculating the rutting depth sustaining the measured modulus of elasticity of asphalt concrete. With reference to a previously accomplished experimental research, it is possible to estimate the efficiency of geosynthetic materials in asphalt concrete pavements and increase the modulus of elasticity of asphalt concrete. The regression model can by used to predict the rutting depth in new asphalt concrete pavements. The increase of the modulus of elasticity by $10 \%$ reduces the depth of rutting by $14 \%$. 


\section{References}

1. Uzan, J. Permanent Deformation in Flexible Pavements. Journal of Transportation Engineering, 130(1), 2004, p. 6-13.

2. Fwa, T. F.; Tan, S. A. and Zhu, L. Y. Rutting Prediction of Asphalt Pavement Layer Using C - $\phi$ Model. Journal of Transportation Engineering, 130(5), 2004, p. 675-683.

3. Sivilevičius, H. and Petkevičius, K. Regularities of Defect Development in the Asphalt Concrete Road Pavements. Journal of Civil Engineering and Management, 8(3), 2002, p. 206-213.

4. State Road Maintenance and Development Programme of the Republic of Lithuania in 2002-2015 (2002-2015 metu Lietuvos Respublikos valstybinès reikšmès kelių priežiūros ir plètros programa), Vol II. Lithuanian Road Administration under the Ministry of Transport and Communications. Kaunas, 2001, p. 93 (in Lithuanian).

5. Laurinavičius, A. and Čygas, D. Thermal Conditions of Road Pavements and Their Influence on Motor Traffic. Transport, 18(1), 2003, p. 23-31.

6. Topal, A. and Sengoz, B. Determination of Fine Aggregate Angularity in Relation with the Resistance to Rutting of Hot-mix Asphalt. Construction and Building Materials, 19(2), 2005, p. 155-163.

7. Grabowski, W. and Wilanowicz, J. Influence of Structural Parameters of Mineral Fillers on their Functional Features - Research and Mathematical Modelling. Archives of Civil Engineering, 50(1), 2004, p. 161-173.

8. Vislavičius, K. Determination of Optimum Quantity of Bitumen in Asphalt Concrete Mixtures. Journal of Civil Engineering and Management, 8(1), 2002, p. 73-76.

9. The Shell Bitumen Handbook. Cherstey: Design and Print Partnership Limited, 1991. 336 p.

10. Čygas, D. Main Problems of Manufacturing Asphalt Concrete Mixtures in Lithuania. Statyba (Civil Engineering), 6(1), 2000, p. 39-45 (in Lithuanian).

11. Grabowski, W.; Słowik, M. and Kuczma, M. S. Modelling the Creep Experimental Results for a Polymer Modified Bitumen. Archives of Civil Engineering, 50(1), 2004, p. $151-160$.
12. Perkins, S. W. and Edens, M. Q. Finite Element and Distress Models for Geosynthetic-Reinforced Pavements. International Journal of Pavement Engineering, 3(4), Dec 2002, p. 239-250.

13. Perkins, S. W. Numerical Modelling of Geosynthetic Reinforced Flexible Pavements. Report No FHWA/MT01-003/99160-2, Montana Dept of Transportation, Helena, Montana, USA, 2001. 97 p.

14. Kim, K. W.; Doh, Y. S. and Lim, S. Mode I Reflection Cracking Resistance of Strengthened Asphalt Concretes. Construction and Building Materials, 13(5), 1999, p. 243-251.

15. Cleveland, G. S.; Button, J. W. and Lytton, R. L. Geosynthetics in Flexible and Rigid Pavement Overlay Systems to Reduce Reflection Cracking. Report No 0-1777, Texas Transportation Institute, 2002. 298 p.

16. Huang, Y. H. Pavement Analysis and Design. Prentice Hall Englewood Cliffs, New Jersey. 1993. 805 p.

17. Gunin, S. O., Kiselev, S. O. Experimental Research of Flexible Pavements of Transitional and Lower Types, Temporary Roads Reinforced with Geogrids. In: Proc of 2nd International Scientific-Technical Conference, St. Petersburg, Russia, 2002, p. 92-96.

18. Perkins, S. W. Geosynthetic Reinforcement of Flexible Pavements: Laboratory Based Pavement Test Sections. Report No FHWA/MT-99-001/8138, Montana Department of Transportation, Helena, Montana, USA, 1999. $140 \mathrm{p}$.

19. LST 1360.5:1995. Soils for Road Construction. Testing Methods. Plate Load Test. Lithuanian Standards Board (Automobilių keliu gruntai. Bandymo metodai. Bandymas štampu). Vilnius, 1995, p. 14 (in Lithuanian).

20. Karalevičius, I. and Sivilevičius, H. The Dynamics of Changes in Asphalt Concrete Mixture Composition in Storage, Transportation and Lying. In: Proc of 6th International Conference Environmental Engineering, Vilnius, 26-27 May 2005. Selected papers, eds D. Čygas and K. D. Froehner. Vilnius: Technika, 2005, p. 719-725.

\section{EKSPERIMENTINIAI PROVĖŽU ATSIRADIMO IR VYSTYMOSI TYRIMAI ASFALTBETONIO DANGOSE, ARMUOTOSE GEOSINTETINĖMIS MEDŽIAGOMIS}

\section{A. Laurinavičius, R. Oginskas}

\section{S antrauka}

Išnagrinètos pagrindinès šlyties deformacijų ir provėžų asfaltbetonio dangose susidarymo priežastys bei pagrindiniai būdai šioms deformacijoms mažinti. Geosintetinių medžiagų ịtaka šioms deformacijoms nagrinèjama remiantis reologinèmis asfaltbetonio charakteristikomis: asfaltbetonio tampros moduliu ir asfaltbetonio klampumu. Geosintetinėmis medžiagomis armuotų asfaltbetonio dangų tyrimai atlikti eksperimentiniame bandymų ruože, Vilniaus mieste, naudojant statinị bandymo štampą. Remiantis gautais tyrimų rezultatais išvestos priklausomybès, kaip prověžu gyli lemia geosintetinès medžiagos, ir asfaltbetonio tampros modulis. Šiame straipsnyje pateiktos regresinès priklausomybės, atspindinčios, kaip prověžų gylis priklauso nuo asfaltbetonio tampros modulio.

Reikšminiai žodžiai: asfaltbetonis, asfaltbetonio armavimas, geosintetinès medžiagos, asfaltbetonio tampros modulis, provèžų gylis.

Alfredas LAURINAVIČIUS. Head of Roads Dept of Vilnius Gediminas Technical University, PhD, Prof. Research interests: new technologies in road building, roads climatology, traffic safety, investigation of road materials.

Rolandas OGINSKAS. PhD student in Dept of Roads, Vilnius Gediminas Technical University. Research interests: asphalt pavements design, new technologies in pavements. 